\title{
MEASURING SURFACE GEOMETRY OF AIRPLANE WING BY MEANS OF TWO METHODS
}

\author{
Domantas Bručas ${ }^{1}$, Jūratė Sužiedelytė-Visockienè ${ }^{2}$ \\ Department of Geodesy and Cadastre, Vilnius Gediminas Technical University, \\ Saulètekio al. 11, LT-10223 Vilnius, Lithuania, \\ E-mails: ${ }^{1}$ domka@ktv.lt, ${ }^{2}{ }_{j}$ visockiene@hotmail.com
}

Received 18 March 2009; accepted 5 May 2009

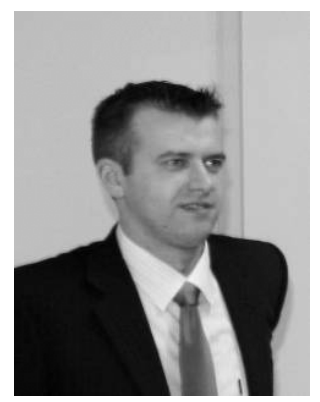

Domantas BRUČAS, Dr

Date and place of birth: 1979, Vilnius, Lithuania.

Education: Vilnius Gediminas Technical University.

Affiliation and functions: Assoc Prof at Vilnius Gediminas Technical University.

Research interests: development and investigation of comparator for angular measurements, automation of the processing the measurement results.

Publications: over 15 articles.

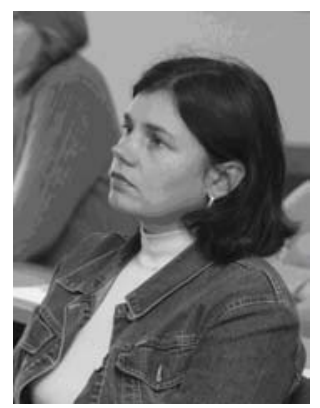

Jūratė SUŽIEDELYTĖ-VISOCKIENĖ, Doc Dr

Date and place of birth: 1971, Lithuania.

Education: Vilnius Gediminas Technical University.

Affiliation and functions: Assoc Prof at Vilnius Gediminas Technical University.

Research interests: digital photogrammetry, land management.

Publications: over 15 articles.

\begin{abstract}
Determination of the geometry of aircraft surfaces has always been an extremely complicated task, though it is very important for the aerodynamic properties of the entire aircraft or its parts (like wings, body, rudders, etc.). Measurement of the geometrical properties of aircraft parts is especially difficult due to the smoothness of their surfaces. Here in this paper a short review of two methods of determining the shape of aircraft parts are given: one relies on determining point position by means of laser-based scanning and another relies on photogrammetry. A comparison of the results of both methods applied to the same aircraft element is also presented.
\end{abstract}

Keywords: tacheometer, laser distance meter, photogrammetry, point cloud, CAD model, accuracy of measurement.

\section{Introduction}

As is widely known, the accuracy of the production of aircraft aerodynamic components is a complicated task largely influencing the aerodynamic properties of the entire aircraft. Additionally, the exploitation of the aircraft could cause some significant changes in the shape of its aerodynamic surfaces. The shape and the surface flaws of aircraft elements should therefore be controlled quite precisely (1-5 $\mathrm{mm})$.

Despite the influence of the shape of aerodynamic surfaces on the properties of the flight of aircraft, the geometric shape of those aerodynamic elements is quite seldom precisely controlled due to the complexity of such 
control. The surface (and the general shape) of the assembled aircraft can hardly be controlled by the contact measurements due to the large size of the entire aircraft; such large coordinate measuring machines can be installed at special plants and are extremely expensive. The control of dimensions by means of the arm-type coordinate measuring machines is possible, but such an approach is not always applicable too due to the quite complex surface, the need for constant repositioning of the instrument (producing additional errors), and the quite high price of the instrument. Additionally, such approaches require mechanically touching aircraft surfaces with the touch probe, and thus obtaining the large point cloud required for the evaluation of the shape and surface is very time consuming. The application of laser scanning coordinate measuring machine probes is also possible, but these touch probes are even more expensive.

Measuring the shape of the aircraft (especially the wings) using a classical hard template cannot give exact surface errors or determine the entire shape of the element and is also very time consuming.

For the determination of the shape of aircraft elements like wings, fuselage, rudders, etc. mostly optical (non-contact) measuring methods could be successfully used. Here in this paper we present a very brief review of two measuring methods which can be applied for the determination of the shape of aircraft elements by means of the collection of optical surface points. Those methods being: point collection by means of an electronic tacheometer working in the surface scanning mode and the collection of surface points by means of photogrammetric measurements. A comparison of the results of the implementation of both methods on the same aircraft element in laboratory conditions is also presented.

\section{The experiment}

For the experiment of measuring the shape of aircraft components in laboratory conditions, part of an aircraft wing was chosen. The experiment consisted of two parts: measurement of the surface (obtaining the point cloud) by means of laser scanning by geodetic tacheometer and obtaining the point cloud by means of photogrammetry.

General arrangement of the instruments is shown in figure 1; a measured wing section (2) was positioned on the stand and special marks (3) used for the orientation of the images during photogrammetric processing were attached both to the stand and the wing itself. A Trimble 5503 electronic tacheometer was used for the wing section surface scan and additionally for obtaining coordinates of marks (3) for the orientation of images in space needed for better coincidence of point clouds acquired by photogrammmetry and tacheometer scanning.

The acquisition of a wing section surface point cloud by means of photogrammetry consisted of taking multiple images with a Canon EOS 350D digital camera (calibrated with $T C C$ software at the Technical University of Bonn) from different directions (to obtain a stereo view). Since for point determination (especially in automated mode) by means of photogrammetry some different colour or shape points must be visible on the surface (since it is necessary to determine the position of exactly the same point on multiple images) and the surface of the fibreglass plastic wing section was absolutely smooth and had a single colour, some lines were drawn on the surface with a simple permanent marker (Atkinson 2001).

Images of the wing section were taken from all around it and later special marks (Fig 1,3) were used to determine the exact position of the camera while taking the images (for the absolute orientation of the images). Additionally, same marks were measured using the tacheometer (1), thus introducing a single coordinate system both for photogrammetric and tacheometer measurements (Ruzgienè et al. 2005).

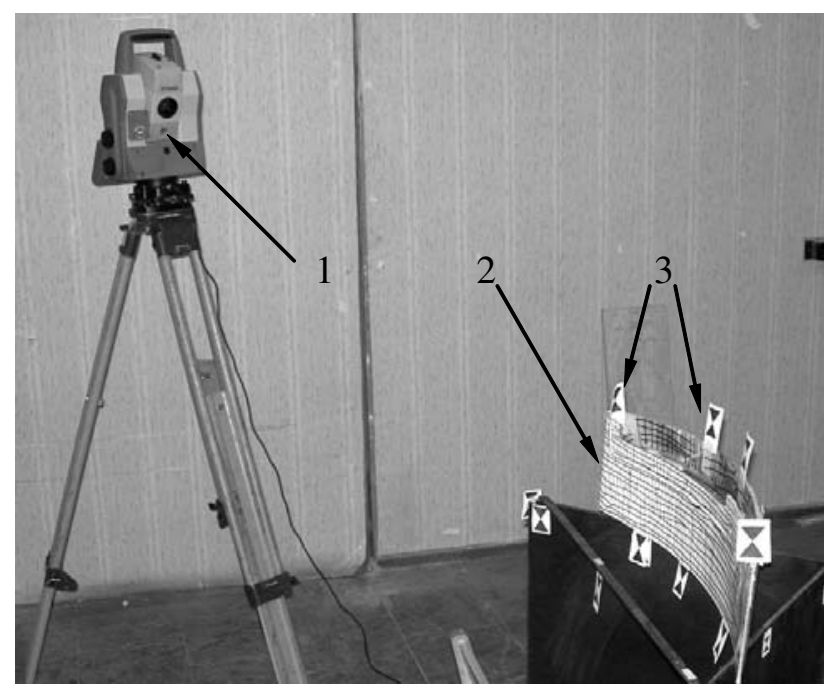

Fig 1. Layout of measuring equipment for experiment: 1 - tacheometer, 2 - tested wing section, 3 - marks

After the images were taken, special PhotoMod photogrammetric software was used for further data processing. With the use of automated point collection from different images (module PhotoMod DTM), a 3D point cloud of the surface of the wing section was obtained (Fig 2).

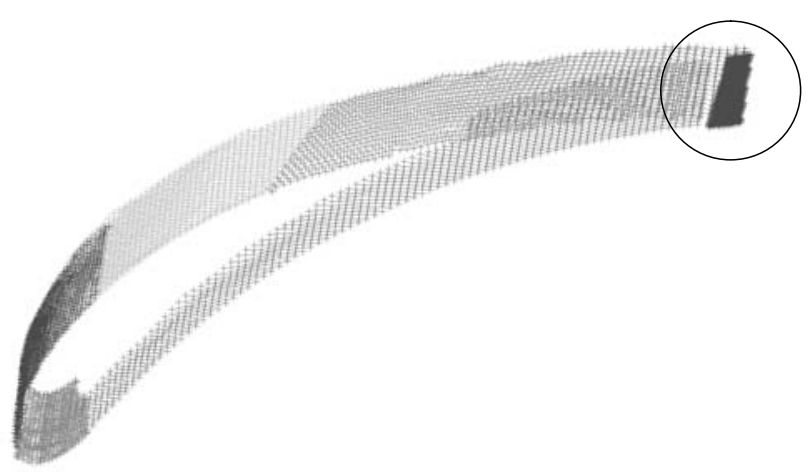

Fig 2. Photogrammetrically obtained wing section surface point cloud (different colours showing section obtained from different mathematic models) with point cloud gap marked 
As can be seen from figure 2, in some areas there is insufficient point cloud density or some gaps in the point cloud obtained from different pairs of images (mathematic models of geometry). Such errors appeared due to too few images taken in some areas and could be corrected by taking some additional images. Such areas were later manually eliminated and not used for further data processing (with the gaps being filled approximately using existing data).

The determination of the expected RMS (Root Mean Square) error in the 3D coordinates of the photogrammetric model (Generation... 2009) :

$$
\mu^{2}=6 / n\left\lfloor t^{2}\left(m_{x, y}^{2}+m_{m o d}^{2}\right)+M_{x, y}^{2}+\left(r^{2} / f^{2} \cos _{e}^{2}\right) M_{H}^{2}\right\rfloor
$$

here $m_{x, y}$ - RMS error in the measurement of the image point when creating the mathematical model of geometry; $m_{\text {mod }}-$ RMS error in the mathematical model of geometry of the image; $M_{x, y}, M_{H}-\mathrm{RMS}$ error in location of control points in plane and in height; $t$ - image scale; $e$ - image inclination angle; $r, f$ - photogrammetric parameters of the images; $n$-number of control points.

The results of the determination of the calculated (theoretical) position of points by the PhotoMod software are shown in table.

Results of determination of calculated (theoretical) position of points by PhotoMod software

\begin{tabular}{|c|c|c|c|c|c|c|c|c|}
\hline $\begin{array}{c}\text { Model } \\
\text { No }\end{array}$ & $\begin{array}{c}M_{x, y} \\
\mathrm{~mm}\end{array}$ & $\begin{array}{c}M_{H} \\
\mathrm{~mm}\end{array}$ & $\begin{array}{c}m_{x, y} \\
\mathrm{~mm}\end{array}$ & $\begin{array}{c}m_{\text {mod }} \\
\mathrm{mm}\end{array}$ & $n$ & $t$ & $e^{\circ}$ & $\mu \mathrm{mm}$ \\
\hline 1 & 0.4 & 0.4 & 0.10 & 0.2 & 6 & $1: 2$ & 1 & 0.45 \\
\hline 2 & 0.8 & 0.3 & 0.06 & 0.3 & 3 & $1: 2$ & 20 & 0.91 \\
\hline 3 & 0.7 & 0.3 & 0.13 & 0.4 & 4 & $1: 2$ & -26 & 1.04 \\
\hline 4 & 0.5 & 0.6 & 0.02 & 0.2 & 6 & $1: 3$ & 40 & 0.61 \\
\hline \multicolumn{10}{|c|}{} & \multicolumn{1}{|c|}{ mean value $0.75 \mathrm{~mm}$} \\
\hline
\end{tabular}

After the point cloud was obtained by photogrammetric software, the data were transferred to Unigraphics CAD software, where the surface using the point cloud was to be created. Due to the complexity of the surface (the closed loop surface), it was decided to make multiple slices of point cloud at a certain pitch and create best fit splines through those sliced points. The reverse engineered surface of the wing section was created through those splines (Fig 3).

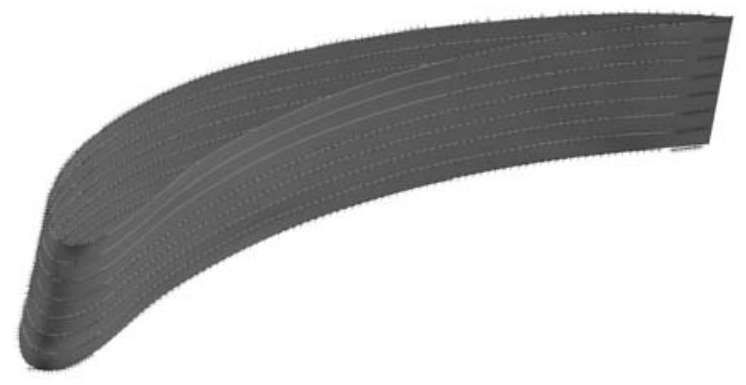

Fig 3. Photogrammetrically obtained sliced point cloud with best fit splines and surface created
The quality of the surface created was checked using mirror reflection surface control mode (Fig 4) or relief mode (Fig 5).

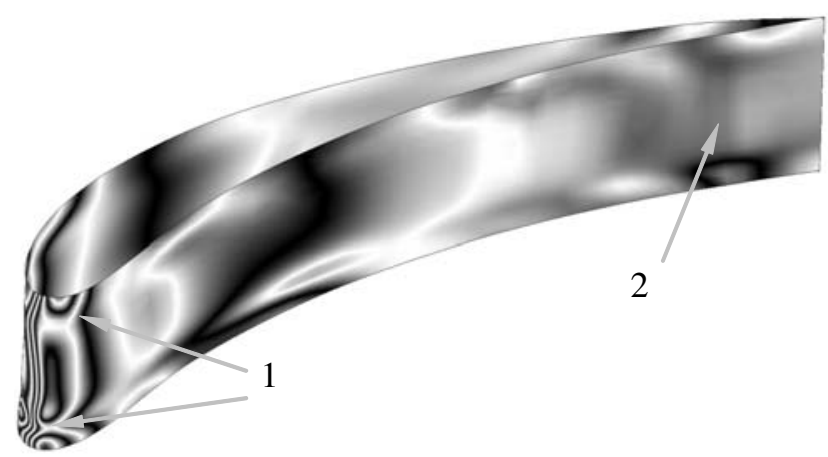

Fig 4. Analysis of surface created by means of mirror reflection: 1 - discrepancies in surface caused by insufficient accuracy of point cloud; 2 - discrepancies caused by gap in point cloud
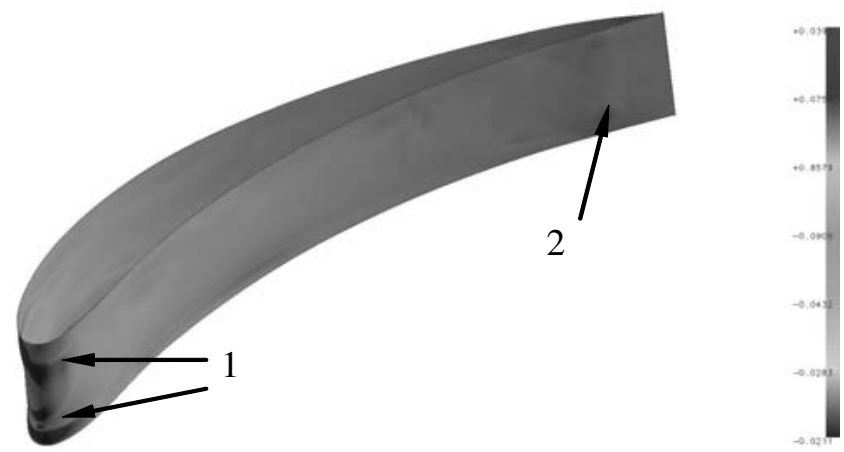

a)

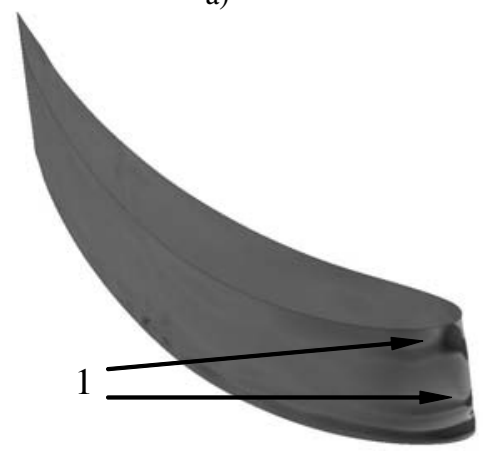

$\sum_{\rightarrow \infty}^{\infty}$

b)

Fig 5. Analysis of surface created by means of relief control: 1 - discrepancies in surface caused by insufficient accuracy of point cloud; 2 - discrepancies caused by gap in point cloud

As can be seen from both figures, there are some discrepancies in the surface of the created wing section at the leading edge (1) and smaller ones near the trailing edge (2) of the wing (Figs 4-5).

The cause of trailing edge discrepancies is quite obvious - the gap in the point cloud (visible in Fig 2) and therefore insufficient accuracy of the surface. Such discrepancies could easily be eliminated after making some additional images of the analyzed part of the wing and thereafter obtaining a larger number of points in the area of the gap. 
The cause of the discrepancies on the surface of the leading edge is not so obvious and probably also arises from an insufficient number of the images being taken at that complexly shaped part of the wing and some light reflection that occurred as the images were being taken (Fig 4,1 and Fig 5). Such discrepancies could be eliminated by taking additional images of the leading edge and probably by more attentive point collection at the part mentioned. Although manual point collection would increase the time needed for point cloud acquisition, it would also increase accuracy.

\section{Control of results}

To control the surface obtained by means of photogrammetry and derive unambiguous results of deviations, measurements of the wing section surface were performed with a Trimble 5503 electronic tacheometer. The measurements were performed in the scanning mode, and therefore the point cloud of the surface was obtained at a certain pitch. To have the point cloud of the entire wing section, the tacheometer was repositioned several times with two stabile points taken as reference.

The scanning techeometer work mode is generally very similar to normal theodolite work; the position of a point is obtained by measuring the horizontal and vertical angle and the distance (by means of a laser distance meter). The same principle is used in modern terrestrial laser scanners, but since a regular tacheometer is not normally intended for surface scanning applications, the scanning process is much more time consuming, though the accuracy of scanning is usually considerably higher.

In the case of the Trimble 5503, the accuracy of point measurement stated by the manufacturer is in the range of $3 \mathrm{~mm}$. Therefore (with the accuracy known) this surface measurement method could be considered a reference to control the surface obtained by means of photogrammetry.

After the surface of the wing section (entire scanning process took about 5 hours) was scanned, the data (point cloud) was transferred to Unigraphics CAD software, where similar to the case in which the point cloud was obtained by photogrammetry, the point cloud was sliced, best fit splines were drawn through the sliced points, and a 3D surface was drawn using those splines (Fig 6).

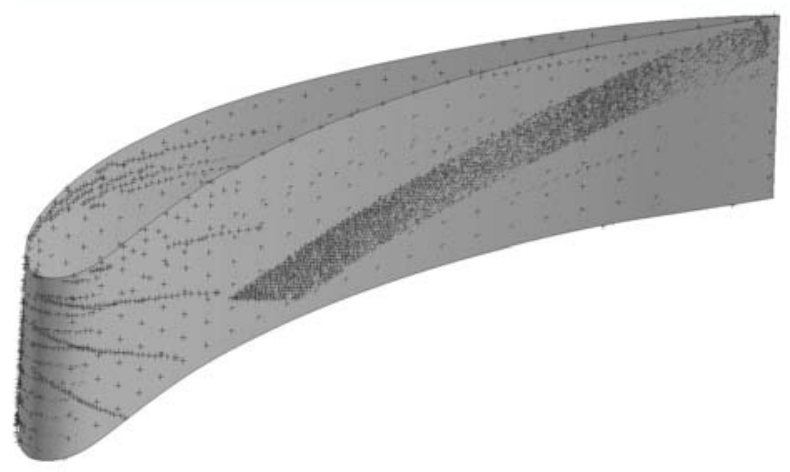

Fig 6. Point cloud of wing section surface obtained by scanning tacheometer with 3D surface created
Since the coordinate system in both photogrammetric and tacheometer measurements was the same (the same control points with the same coordinates were used), it was easy to match the surfaces created from the point clouds obtained by the photogrammetric and tacheometer measurements (Fig 7).

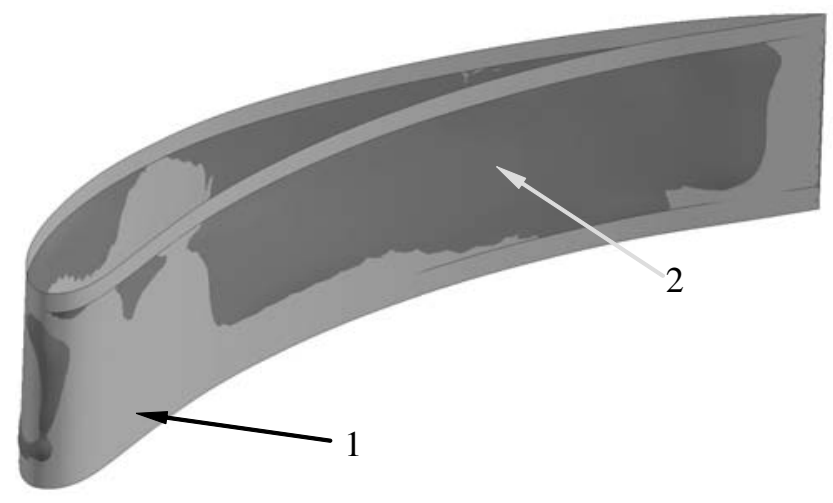

Fig 7. 3D comparison of the surfaces: 1 - created from point cloud obtained by tacheometer measurements; 2 - by photogrammetric measurements

As can be seen from figure 7 , the discrepancies in the surface obtained by photogrammetric measurements are obvious at the leading edge of the wing section, though trailing edge discrepancies are not so visible. In general, after visual comparison of both surfaces, it can be noted that the differences are quite minor. Exact deviations at the cross section of the largest differences are shown in figure 8.

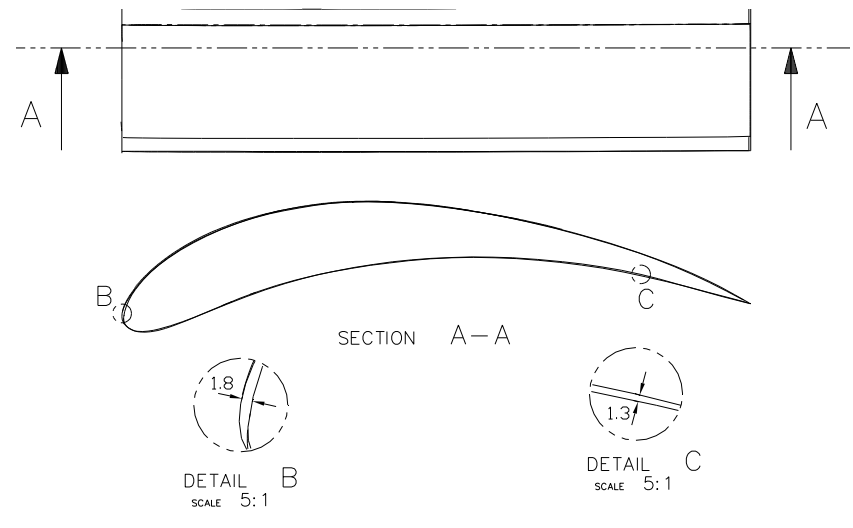

Fig 8. Comparison of surfaces created from photogrammetric and tacheometer measurement data at the cross section of the largest deviations

Judging from the cut section shown in figure 8 , it might be stated that maximal deviation of the photogrammetricaly obtained point cloud compared to the one obtained by the tacheometer measurements does not exceed $2 \mathrm{~mm}$ (taking the largest area of deviations). Such measurements therefore show quite good accuracy.

\section{Comparison of measurement methods}

In summary, to get the entire picture of the free-form surface measurements described, some of the advantages and disadvantages of the measuring methods (photogram- 
metry and tacheometer-based laser scanning) can be highlighted.

The main advantages of the tacheometer-based laser scanning are the following:

- High accuracy of measurements; the stated accuracy of the tacheometer used was $3 \mathrm{~mm}$ (though for normal laser scannersit seldom exceeds $4 \mathrm{~mm}$ );

- Measurements can be done on almost any surface (though the colour and textureof the surface present some errors);

- The point cloud is produced almost immediately after the measurements, and thus measurement errors can be spotted and measurements repeated if necessary (Suchocki 2008);

- Instruments such as electronic tacheometers are widely used in geodesy, building construction, and other branches of industry, and they are therefore quite available.

Tacheometer-based laser scanning method has its disadvantages too:

- The method is very time consuming (some $20 \mathrm{~min}$ are required to acquire 100 points), though when a terrestrial laser scanner is used, the point acquisition time is very short;

- The high price of the instrument (terrestrial laser scanners are especially expensive).

The advantages of the photogrammetric free-form surface point cloud measurements are:

- The relative cheapness of the measurements - only a single quite high accuracy camera and special software are needed (Ruzgienè 2008);

- The possibility of obtaining a point cloud of quite high accuracy (in classical digital close range photogrammetry, it is considered that achieving the accuracy of point coordinate determination of $\pm 0.01 \%$ from the distance to the object is quite possible), though highly dependent on the environment (Karara 1997);

- The possibility of correcting the results (obtaining additional points) with only the images and without the need of measuring the object itself.

The main disadvantages of the photogrammetric method in the case described (measurement of airplane surfaces) are:

- The need of producing some artificial colour differences on the surface since it is absolutely smooth and colourless on most modern airplanes. Usually such colour differences are produced by projecting different colour light on the measured object (then there is no need to make any temporary marks) (Atkinson 1980 );

- Due to its entirely optic nature, measurements are highly dependent on the environmental conditions;

- The accuracy of measurements is highly dependent on camera calibration, which is quite difficult to accomplish and requires special facilities and software (though such calibration is required very rarely) (Sonka et al. 1998 );

- Results of measurements cannot be immediately seen and therefore evaluated; data processing must be performed mostly on a special computer in the office environment and all data processing requires time even in automated mode.

\section{Conclusions}

In conclusion it might be said:

- Two methods of determining the surface dimensions of a complex shape (photogrammetric and tacheometer-based laser scanning), both of which can be used to measure aircraft surfaces, were tested in laboratory conditions.

- Despite the differences in the principles of measuring a single section of wing with the two different measurement methods, the deviations between the two methods did not exceed $2 \mathrm{~mm}$, which is in the range of accuracy of method (tacheometer scanning) considered as the reference one.

- Both methods have their advantages and disadvantages, and thus both (in different conditions) can be used for the measurement of aircraft surfaces having a complex shape.

- Additional tests of the methods used should be performed in different environmental conditions, such as open aircraft storage fields, aircraft hangars, and construction facilities.

\section{References}

Atkinson, K. B. 1980. Development of photogrammetry and surveying. London: Applied Science Publishers LTD. 222 p.

Atkinson, K. B. 2001. Close range photogrammetry and machine vision. Scotland UK: Whitteles Publications, KW5 6DW. 371 p.

Generation of DTM using Russian images (online). 2009. Available from internet: <http://www. sovinformsputnik.ru/images/dtm_gim.pdf $>$.

Karara, H. M. 1997. Handbook of non-topographic photogrammetry. VA: American Society of Photogrammetry, North Virginia Ave, Falls Church. 206 p.

Ruzgienè, B. 2008. Fotogrametrija. Vilnius: Technika, 203 p.

Ruzgienè, B.; Fröhner, W. 2005. RANSAC for outlier detection. Geodesy and cartography, 31(3). Vilnius: Technika, 83-87.

Sonka, M., Hlavac, V., Boyle, R. 1998. Image Processing, Analysis, and Machine Vision. Iowa: PWS. $260 \mathrm{p}$.

Suchocki, C. 2008. Application of scanning technology in cliff shores monitoring. In The 7th International conference "Environmental engineering": Selected papers, vol. 3. May 22-23, Vilnius, Lithuania. Vilnius: Technika, 1493-1496. 


\section{ORLAIVIO SPARNO GEOMETRIJOS MATAVIMAS DVIEM METODAIS}

\section{Bručas, J. Sužiedelytè-Visockienè}

\section{S a n trauka}

Orlaivio paviršiaus geometrijos nustatymas visada buvo labai sudėtinga užduotis, nors tai labai svarbu orlaivio dalių (sparnų, liemens, vairų ir kt.) ar viso orlaivio aerodinaminių charakteristikų kontrolei. Nustatyti geometrinių orlaivio detalių matmenis yra ypač sudėtinga dẻl jų lygaus paviršiaus. Šiame straipsnyje trumpai aprašyti du orlaivio dalių paviršiaus formos nustatymo metodai: vienas remiasi taškų koordinačiu nustatymu naudojant lazerinio skenavimo tipo matavimus, kitas - fotogrametrinius matavimus. Taip pat pateiktas abiejų metodų palyginimas taikant juos to paties orlaivio elemento formos nustatymui.

Reikšminiai žodžiai: tacheometras, lazerinis tolimatis, fotogrametrija, taškų debesis, CAD modelis, matavimų tikslumas. 